\title{
A Review on the Structure and Anti-Diabetic (Type 2) Functions of $\beta$-Glucans
}

\author{
Yujun Wan ${ }^{1} \mathbb{D}$, Xiaojuan $X u^{2}$, Robert G. Gilbert ${ }^{1,3, * \mathbb{D}}$ and Mitchell A. Sullivan ${ }^{4, *}$ \\ 1 Centre for Nutrition and Food Sciences, Queensland Alliance for Agriculture and Food Innovation, \\ The University of Queensland, Brisbane, QLD 4072, Australia; y.wan@uq.edu.au \\ 2 College of Chemistry and Molecular Sciences, Wuhan University, Wuhan 430072, China; xuxj@whu.edu.cn \\ 3 Joint International Research Laboratory of Agriculture and Agri-Product Safety, College of Agriculture, \\ Yangzhou University, Yangzhou 225009, China \\ 4 Glycation and Diabetes Group, Mater Research Institute, The University of Queensland, \\ Translational Research Institute, Brisbane, QLD 4072, Australia \\ * Correspondence: b.gilbert@uq.edu.au (R.G.G.); mitchell.sullivan@mater.uq.edu.au (M.A.S.)
}

Citation: Wan, Y.; Xu, X.; Gilbert, R.G.; Sullivan, M.A. A Review on the Structure and Anti-Diabetic (Type 2) Functions of $\beta$-Glucans. Foods 2022, 11, 57. https://doi.org/10.3390/ foods 11010057

Academic Editor: Diego A. Moreno

Received: 29 November 2021

Accepted: 24 December 2021

Published: 27 December 2021

Publisher's Note: MDPI stays neutral with regard to jurisdictional claims in published maps and institutional affiliations.

Copyright: (c) 2021 by the authors Licensee MDPI, Basel, Switzerland. This article is an open access article distributed under the terms and conditions of the Creative Commons Attribution (CC BY) license (https:// creativecommons.org/licenses/by/ $4.0 /)$.

\begin{abstract}
Type 2 diabetes, a long-term chronic metabolic disease, causes severe and increasing economic and health problems globally. There is growing evidence that $\beta$-glucans can function as bioactive macromolecules that help control type 2 diabetes with minimal side effects. However, conflicting conclusions about the antidiabetic activities of $\beta$-glucans have been published, potentially resulting from incomplete understanding of their precise structural characteristics. This review aims to increase clarity on the structure-function relationships of $\beta$-glucans in treating type 2 diabetes by examining detailed structural and conformational features of naturally derived $\beta$-glucans, as well as both chemical and instrumental methods used in their characterization, and their underlying anti-diabetic mechanisms. This may help to uncover additional structure and function relationships and to expand applications of $\beta$-glucans.
\end{abstract}

Keywords: type 2 diabetes; $\beta$-glucan; molecular structure; anti-diabetic function; macronutrient absorption; enzyme inhibitor

\section{Introduction}

Type 2 diabetes (T2D), a disease associated with insulin resistance and poor blood glucose control, is a major public concern due to the potential severe complications and associated morbidity and its increasing rate of occurrence in many developed and developing countries. The major characteristic of this metabolic disease is chronic hyperglycemia, with severe complications leading to the long-term damage of various organs, including the eyes, kidneys, heart, blood vessels and nerves [1]. According to projections from the International Diabetes Federation, it has been estimated that in 2019 there were 463 million people with diabetes globally, and this is expected to reach 700 million by 2045, which will cost US $\$ 850$ billion per year for diabetes healthcare [2,3]. Although several drugs have been used clinically to control T2D, such as biguanides [4], sulfonylureas [5], sodiumglucose co-transporter-2 (SGLT2) inhibitors [6], and thiazolidinediones [7], all of these drugs have some serious side-effects, especially resulting in gastrointestinal disorders $[8,9]$ which affect both the drugs' efficacy and the patient's life. "Natural" medicine based on the concept of "food as medicine" has been proposed as an alternative strategy in the managing of metabolic diseases (such as T2D), due, among other things, to their safety [10]. Growing evidence has confirmed that certain bioactive nutrients in these foods, including polysaccharides [11,12], can help mitigate metabolic abnormalities [13].

Polysaccharides, one of the most important biomacromolecules for life, are polymers found in natural sustainable resources. From 1970, since the first discovery of the bioactive properties of lentinan, there has been a drive to research the biological functions of 
polysaccharides $[14,15]$. $\beta$-glucans are a type of naturally-derived polysaccharide which can be widely found in bacteria, alga, fungi, cereals, and higher plants. They are generally biopolymers with $\beta$-glucopyranosyl units, which normally contain a $\beta$-(1,3)-linked and/or $\beta$-(1,4)-linked backbone and may be branched with $\beta-(1,6)$-linked glucose.

$\beta$-glucans have been used in the food industry and in clinical practice because of their significant biological functions. For example, $\beta$-glucans with high molecular weights have been reported to enhance the binding capacity to the receptors involved in immune responses (e.g., dectin-1: a natural killer (NK)-cell-receptor-like C-type lectin involving in innate immune responses) and therefore improve their immunomodulatory activities, which can help to control some chronic diseases such as diabetes [16]. However, many studies have reported that degrading $\beta$-glucans to yield lower molecular weights can increase their anti-diabetic effects in vitro, as well as their antioxidant and antibacterial activities $[17,18]$. These differences in reported results may arise from differences in the detailed molecular structures of the substrates [19]. Therefore, this paper reviews structural and conformational features of naturally derived $\beta$-glucans, summarizing the potential underlying mechanisms of their anti-diabetic functions, for a better understanding of the structure-function relationships of $\beta$-glucans.

\section{Structural Features of $\beta$-Glucans}

It is commonly asserted that the functionalities of $\beta$-glucans are highly dependent on their molecular structure. The structural characteristics of $\beta$-glucans, including molecular weight distributions, glycosidic linkage patterns and branching degrees, vary with different sources and extraction methods. There are three main glycosidic linkage patterns identified in $\beta$-glucans (Figure 1): $\beta$-1,3-linked, $\beta$-1,4-linked and $\beta$-1,6-linked patterns. Normally, $\beta$ 1,3 -linked and $\beta$-1,4-linked patterns appear in the backbone of $\beta$-glucan, and $\beta$-1,6- linkages represent the branch points in the backbone.

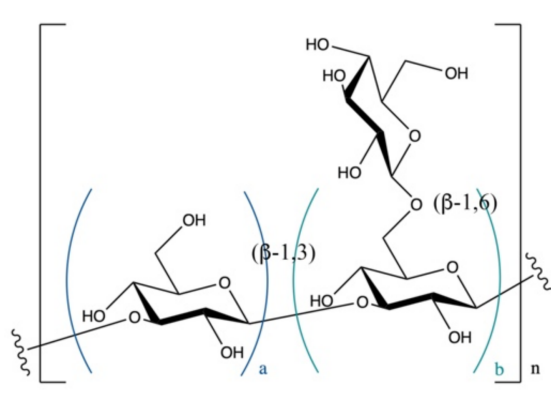

A

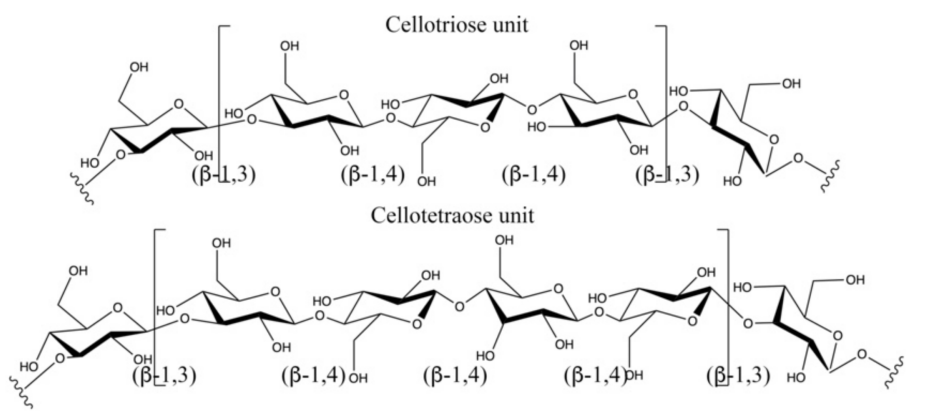

B

Figure 1. Chemical structures of $\beta$-glucans. The glucose monomers are shown following the symbol nomenclature for glycans. (A) The $\beta$-1,3-linked backbone of $\beta$-glucan with different branching degree of $\beta$-1,6-linked glucose. (B) The $\beta$-1,3-1,4-linked backbone of $\beta$-glucan, DP3: cellotriosyl, DP4: cellotetraosyl).

Branched or linear $\beta$-1,3-glucans (Figure 1A) are commonly isolated from fungi (e.g., mushroom [20]) and bacteria (e.g., yeast [20]). The occurrence of $\beta$-1,3-linkages together with $\beta$-1,4-linked glycosidic bonds (Figure 1B) are observed in the $\beta$-glucans from cereal grains (e.g., oat [21]). As shown in Figure 1B, there are two types of oligosaccharide subunits; one is three $\beta$-1,4-linked glucose monomers, termed cellotriosyl (DP3), and the other type is $\beta$-1,4-linked glucose monomers called cellotetraosyl (DP4). The molar ratio of DP3 and DP4 in $\beta$-glucans is specific for different cereals; this can be used as a tool to trace the origin of a given $\beta$-glucan structure [21].

The extraction methods of $\beta$-glucans vary from sample to sample. There are commonly four types of isolation method used in extracting $\beta$-glucans, such as water extraction [22-24], alkaline extraction [25,26], acidic extraction [27] and enzymatic extraction [28]. Some suggested structures of naturally derived $\beta$-glucans are shown in Table 1 . These structures 
are generally inferred from a combination of results collected by both chemical tests and instrumental analysis. Interestingly, some similar repeating structural units exist in several $\beta$-glucans from different sources. For example, $\beta$-glucans from Dictyophora indusiate, Hericium erinaceus, Grifola frondosa, Schizophyllan and brown algae have the same repeating unit, viz., three $\beta$-1,3-Glc $p$ backbone residues with a branch comprising one $\beta$-1,6-linked glucose residue. The branches of $\beta$-glucans, connected to the backbone via $\beta-1,6$ glycosidic bonds, play a major role in the solubility of the $\beta$-glucan. For example, curdlan, a linear $\beta$-glucan (i.e., without side chains) is insoluble in water [29], while the $\beta$-glucans with branched glucose residues, such as lentinan and Schizophyllan, are water-soluble [30,31]. However, these $\beta$-glucans exhibit some hydrophobicity due to hydrophobic carbon rings, resulting in limited water-solubility. Thus, $\beta$-glucans adopt different chain conformations to achieve stability. It is essential to consider their chain conformations in different solvents for the application of $\beta$-glucans in the food industry and medicine.

Table 1. Sources and deduced chemical structures of several $\beta$-glucans.

\begin{tabular}{|c|c|c|c|c|c|}
\hline Name/Abbr. & Source & Extraction Solvent & Type of Glucan & Structure $^{a}$ & Ref. \\
\hline Curdlan & Alcaligenes faecalis var. & $\mathrm{NaOH}$ & $\beta-1,3$ glucan & (A) $a=1, b=0$ & {$[25,26]$} \\
\hline APP & Auricularia auricula & $\mathrm{NaCl}$ & $\beta-1,3$ glucan & (A) $a=1, b=2$ & [32-34] \\
\hline DIP & Dictyophora indusiata & Water & $\beta-1,3$ glucan & (A) $a=2, b=1$ & [22-24] \\
\hline HEP & Hericium erinaceus & Water & $\beta-1,3$ glucan & (A) $a=2, b=1$ & {$[35,36]$} \\
\hline GFP & Grifola frondosa & Water & $\beta-1,3$ glucan & (A) $a=2, b=1$ & [37-39] \\
\hline Schizophyllan & Schizophyllum & Water & $\beta-1,3$ glucan & (A) $a=2, b=1$ & {$[30,40]$} \\
\hline Laminarin & Algae & Water & $\beta-1,3$ glucan & (A) $a=2, b=1$ & {$[41,42]$} \\
\hline Lentinan & Lentinula edodes & $\mathrm{NaCl} / \mathrm{NaOH}$ & $\beta-1,3$ glucan & (A) $a=3, b=2$ & {$[31,43]$} \\
\hline GLP & Ganoderma lucidum & Water & $\beta-1,3$ glucan & (A) $a=5, b=1$ & {$[44,45]$} \\
\hline YBG & Saccharomyces cerevisiae & $\mathrm{NaOH}$ & $\beta-1,3$ glucan & (A) $a=5, b=1$ & [46] \\
\hline CSP & Wild Cordyceps sinensis & Water & $\beta-1,3$ glucan & (A) $a=5, b=2$ & [47] \\
\hline WBG & Wheat & Water & $\beta-1,3-1,4$ glucan & (B) DP3:DP4 = 3.0-4.5 & {$[21,48]$} \\
\hline BBG & Barley & Water/NaOH & $\beta-1,3-1,4$ glucan & (B) $\mathrm{DP} 3: \mathrm{DP} 4=1.7-3.3$ & {$[48,49]$} \\
\hline RBG & Rye & Water & $\beta-1,3-1,4$ glucan & (B) $\mathrm{DP} 3: \mathrm{DP} 4=1.8-3.1$ & [50-52] \\
\hline OBG & Oat & Water & $\beta-1,3-1,4$ glucan & (B) $\mathrm{DP} 3: \mathrm{DP} 4=1.5-2.2$ & {$[48,53]$} \\
\hline
\end{tabular}

${ }^{a}$ The uppercase letters within this column represent the repeating units shown in Figure 1 (A. $\beta-1,3-1,6$ glucan; B. $\beta-1,3-1,4$ glucan). The lowercase letters indicate the molar ratio of each part in the repeating units.

\section{Conformational Features of $\beta$-Glucans}

Several chain conformations of $\beta$-glucans are found in different solutions (Figure 2), from a disordered conformation (e.g., random coil) to an ordered conformation (e.g., helix conformation). These more organized conformations can easily form a stable network (e.g., a triple helix), and the stabilization of this network arises from its inter- and intra-molecular hydrogen bonds. However, the dense triple helix conformation formed by the interaction of intramolecular polyhydroxy groups may result in its insolubility in aqueous solution [54].

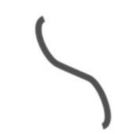

Worm-like

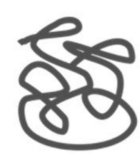

Random coil

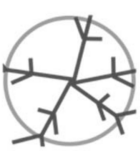

Sphere

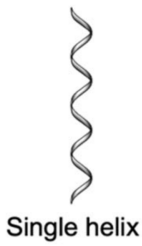

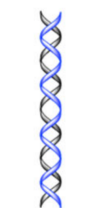

Double helix

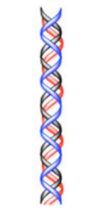

Triple helix

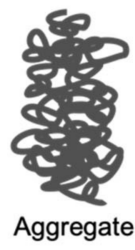

Aggregate

Figure 2. Various chain conformations of polysaccharides in different solvents.

There are many parameters that can affect conformational features of polysaccharides, including the molar mass per unit of contour length $\left(M_{L}\right)$, the contour length of chains $(L)$, the persistence length $(q)$ and the chain diameter $(d)$. The contour length of a polymer chain refers to its length at maximum physically possible extension, and the persistence length reflects the bending stiffness of a chain. Several reports indicate that $\beta$-glucans that 
exhibit strong biological functions show a triple-helix conformation, such as lentinan [55], curdlan [56] and yeast $\beta$-glucan [57]. Based on both theoretical and experimental results, the $M_{\mathrm{L}}$ and $q$ values of a polysaccharide with a rigid triple-helix conformation usually range from 2000 to $2800 \mathrm{~nm}^{-1}$ and from 100 to $250 \mathrm{~nm}$, respectively [20]. For example, lentinan, the first reported $\beta$-glucan with antitumor activities, exists as a triple-helix conformation in aqueous solution, with a reported $M_{\mathrm{L}}$ value of $2160 \mathrm{~nm}^{-1}$ and $q$ value of $110 \mathrm{~nm}$ [58]. Schizophyllan, a widely studied $\beta$-glucan from Schizophyllum, has a reported $M_{\mathrm{L}}$ value of $2150 \mathrm{~nm}^{-1}$ and $q$ value of $200 \mathrm{~nm}$ [59]. However, the triple-helix conformation of these $\beta$-glucans can be transferred to other conformations under special conditions, such as high temperature [60], high pH solvents [61] and strong polar solvents [62]. With disrupted conformations, their bioactivities and solubilities are also changed. Therefore, the structural and conformational features of $\beta$-glucan need to be well characterized for a correct understanding of their functionalities.

\section{Characterization Methods for $\beta$-Glucan Structure and Conformation Analysis}

The structural determination of polysaccharides is more complicated than for other biopolymers due to the diverse monosaccharide compositions and glycosidic linkage patterns. In addition to classical chemical characterization methods, many newly developed technologies for the characterization of polysaccharides have been, or could be, employed to help understand the structure-function relationship of bioactive polysaccharides. For example, enzymatic arrays [63] and matrix-assisted laser desorption ionization mass spectrometry [64] have been used to sequence polysaccharides, and ion mobility-mass spectrometry has been developed to analyze carbohydrate anomers [65]. Advanced microscopy techniques, such as atomic force microscopy [66] and confocal laser scanning microscopy [67], provide a new level of microstructure analysis. Recently, low-temperature scanning tunneling microscopy has been successfully applied to observe single glycans [68]. However, the exploration of polysaccharides has been much slower than that of polynucleotides and proteins because of limitations on the structural theories, the complexity of their structures and a poor understanding of the underlying mechanisms of their bioactivities.

The characterization of $\beta$-glucan structure therefore requires a combination of chemical and instrumental analyses (Figure 3). The structural information of $\beta$-glucans usually reported include its purity, molecular weight, monosaccharide composition, anomeric configuration, glycosidic linkage pattern and sequence of residues.

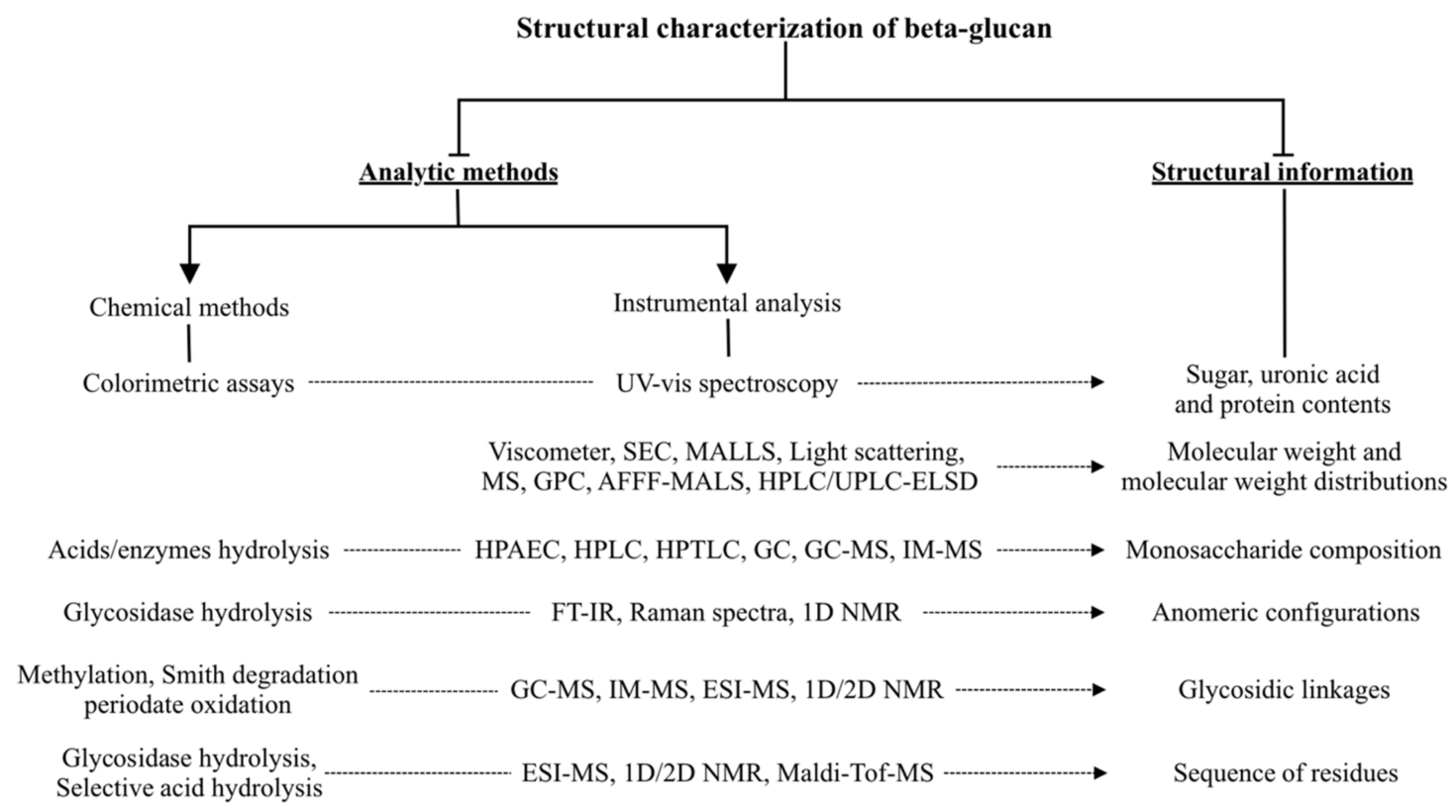

Figure 3. Chemical and instrumental methods used for $\beta$-glucan structure characterization. 
To investigate detailed structure-function relationships of polysaccharides, the "purity" is one of the most important factors. Generally, measuring the purity of $\beta$-glucans includes obtaining several parameters, such as the sugar content and the molecular weight distribution. Colorimetric methods are commonly used as the first step to determine the purity of crude polysaccharides, including the measurement of sugar, uronic acid and protein contents. Then, the molecular weight distributions of polysaccharides can be analyzed using several instrumental methods, such as size exclusion chromatography (SEC). Sometimes, $\beta$-glucans coexists with other polysaccharides, such as arabinogalactans [69]. Therefore, it is essential to analyze its monosaccharide composition to identify the purity of a $\beta$-glucan. Hydrolysis with acids or enzymes is the first step to analyze the monosaccharide composition, after which the hydrolysate is characterized with various instruments. High-performance anion exchange chromatography (HPAEC) is considered one of the most effective instrumental analysis techniques to determine monosaccharide composition due to the high sensitivity and simple sample preparation [70]. A high-purity $\beta$-glucan should have a narrow molecular weight distribution and high glucose content.

Extraction of $\beta$-glucans from grains always results in some starch (an $\alpha$-glucan) [54], and it is difficult to distinguish $\beta$-glucans from $\alpha$-glucans through their sugar content or monosaccharide composition alone. However, a combination of glycosidase hydrolysis and instrumental analysis, such as Raman spectra, FT-IR and NMR, can easily identify the anomeric configuration of glucans. The sequence of residue and the branching degree of naturally derived $\beta$-glucans is highly dependent on its source, and can be characterized using NMR. For a comprehensive characterization of naturally derived $\beta$-glucans, it is necessary to use both chemical methods and instrumental analysis.

To identify the conformation of $\beta$-glucans, weight-average molecular weight $\left(M_{w}\right)$, intrinsic viscosity $([\eta])$, radius of gyration $\left(R_{\mathrm{g}}\right)$ and hydrodynamic radius $\left(R_{\mathrm{h}}\right)$ of $\beta$-glucan samples can be measured by static light scattering (SLS), dynamic light scattering (DLS) and viscometry, using the molecular-weight dependence of their solution properties. Several models, including the helical wormlike chains model and the Kratky-Porod model, can be used to deduce the four main parameters, $M_{\mathrm{L}}, L, q$ and $d$ based on the results of measurements.

Conformation analysis can be performed using X-ray diffraction (XRD), e.g., for measuring the triple-helix $\beta$-glucan [71]. Atomic force microscopy (AFM) is a powerful tool to observe chain conformations in solution, including rod-, sphere- and fiber-like shapes. AFM can provide information on the chain length, chain diameter and even the $M_{\mathrm{L}}$ of a $\beta$-glucan sample [58]. In addition to these experimental techniques, molecular dynamics simulations have been used as a tool to explore the conformation of polymers, which can help illustrate the chain movements and conformations of polymers in different solutions [32], although the results always depend on the assumed model.

Although the characterization of $\beta$-glucans is complicated, an understanding of the structure/function relationships of these molecules is crucial if they are to advance further as a potential antidiabetic drug. Without this understanding the efficacy of a particular $\beta$-glucan is difficult to predict.

\section{Amelioration of Type 2 Diabetes and Associated Mechanisms}

T2D is the most frequent metabolic disorder which involves insulin resistance, followed by deficient insulin secretion by impaired pancreatic islet $\beta$-cells [72]. The two main factors that typically account for T2D are genetic factors and environmental factors. A genome-wide association study has confirmed that there are more than 400 gene variants associated with T2D, with most of them involving islet function [73]. The environmental factors that increase the risk of developing T2D include obesity, alcohol intake and smoking. The predominant factor accounting for T2D is the consumption of unhealthy diets, including those with energy-dense refined food [72]. 


\subsection{Pharmacotherapy for T2D and Anti-Diabetic Mechanisms}

There is a lack of effective drugs to treat T2D due to the complexity of pathogenesis $[72,74]$. However, several drugs are used in controlling T2D, and these drugs can be classified into seven main types based on their structures and mechanisms, including biguanides, sulfonylureas, thiazolidinediones, glucagon-like peptide (GLP-1), dipeptidyl peptidase (DPP-4) inhibitors, sodium-glucose co-transporter-2 (SGLT2) inhibitors and enzyme inhibitors. The underlying mechanisms and potential side-effects of these drugs are summarized in Table 2. As well as the injection of insulin being essential to control type 1 diabetes, this is also adopted to control T2D under certain conditions, such as functional failure of pancreatic islet $\beta$-cells due to the long-term suffering from T2D [75]. However, it should be noticed that all of these anti-diabetic drugs are companied by some severe side-effects (Table 2), such as gastrointestinal disorders, which have prolonged impact on the patient.

Table 2. Drugs used in amelioration of T2D.

\begin{tabular}{|c|c|c|c|c|}
\hline Type & Drug Name & Mechanisms & Side-Effects & Ref. \\
\hline Biguanides & Metformin, Phenformin & $\begin{array}{l}\text { Lowering fasting plasma insulin } \\
\text { concentration; enhancing insulin sensitivity; } \\
\text { changing gut microbiota composition; } \\
\text { promoting functional shifts in } \\
\text { gut microbiome. }\end{array}$ & $\begin{array}{l}\text { Gastrointestinal disorders; folate } \\
\text { deficiency; increasing } \\
\text { homocysteine levels }\end{array}$ & {$[8,76,77]$} \\
\hline Sulfonylureas & Glibenclamide, Glipizide & $\begin{array}{c}\text { As insulin secretagogues to stimulate } \\
\text { insulin secretion. }\end{array}$ & Gastrointestinal disorders, headache & {$[9,78,79]$} \\
\hline Thiazolidinediones & $\begin{array}{l}\text { Rosiglitazone, } \\
\text { Pioglitazone }\end{array}$ & $\begin{array}{l}\text { Improving insulin sensitivity by up-regulation } \\
\text { of adipokine. }\end{array}$ & $\begin{array}{l}\text { Peripheral and pulmonary edema; } \\
\text { fluid retention. }\end{array}$ & {$[80,81]$} \\
\hline GLP-1 & Liraglutide, Semaglutide & $\begin{array}{l}\text { Suppressing glucagon release; delaying } \\
\text { gastric emptying and increasing satiety. } \\
\text { Enhancing incretin axis; improving }\end{array}$ & Nausea, vomiting and diarrhoea & {$[82,83]$} \\
\hline DPP-4 inhibitors & Vidagliptin, Saxagliptin & $\begin{array}{l}\text { meal-stimulated insulin secretion by sparing } \\
\text { incretin hormones. }\end{array}$ & Nausea and gastrointestinal problems & {$[78,84-86]$} \\
\hline SGLT2 inhibitors & $\begin{array}{l}\text { Dapagliflozin, } \\
\text { Cangliflozin }\end{array}$ & $\begin{array}{c}\text { Inhibition of renal glucose reabsorption to } \\
\text { lower plasma glucose levers. }\end{array}$ & $\begin{array}{l}\text { Increasing the risk of developing } \\
\text { diabetic ketoacidosis. }\end{array}$ & {$[6,87]$} \\
\hline Enzyme inhibitors & $\begin{array}{c}\alpha \text {-amylase inhibitors, } \\
\alpha \text {-glucosidase inhibitors, }\end{array}$ & $\begin{array}{c}\text { Reduction in the rate of glucose absorption in } \\
\text { post-prandial blood }\end{array}$ & $\begin{array}{l}\text { Lactic acidosis, diarrhoea, liver } \\
\text { function disorders. }\end{array}$ & [88] \\
\hline
\end{tabular}

\subsection{Glucans Used in Controlling T2D and Underlying Mechanisms}

Naturally derived $\beta$-glucans have been promoted due to their various reported healthpromoting activities and minimal side-effects. They have been widely adopted as healthimproving ingredients to prevent some chronic diseases, especially for T2D. For example, a clinical trial showed that oat $\beta$-glucan can help manage glycemic index, carbohydrate metabolism and alter gut microbiota profile in T2D [89,90]. There are two main underlying mechanisms for the roles of $\beta$-glucans in controlling T2D, which can be explained through their detailed structural and/or conformational features.

\subsubsection{Retardation of Macronutrient Absorption}

Macronutrients within daily diets are necessary for life. However, ongoing quick absorption of these macronutrients in T2D can induce hyperglycemia and hyperlipidemia, and thereby cause metabolic disorders [91]. Hence, a way to help manage T2D is by preventing the absorption of macronutrients, resulting in a reduction in blood cholesterol levels and suppressing the postprandial increase of blood sugar levels [92]. This retardation effect of $\beta$-glucans has been shown to be highly dependent on their molecular weight and concentration. Wood et al. established the relationship of plasma glucose increment (DGpg) and structural features of oat $\beta$-glucan (concentration $(c)$ and weight-average molecular weight $\left(M_{w}\right)$ ) as shown in the formula: DGpg $=A+B \times \log _{10}(c)+0.72 \mathrm{~B} \log _{10}\left(M_{w}\right)$ [93]. In addition, depolymerization of $\beta$-glucans (reducing molecular size) as a result of processing was reported to decrease its effect on decreasing the peak blood glucose response [17].

Additionally, $\beta$-glucans can play a role in increasing the viscosity of a meal during gastrointestinal digestion, limiting the absorption of macronutrients, slowing down gastric emptying, and entrapping bile acids and cholesterol throughout digestion. This lowers 
serum sugar and cholesterol levels in T2D [94]. These benefits are highly dependent on the structure and conformation of $\beta$-glucans, which can be explained by the Mark-Houwink equation for the intrinsic viscosity: $[\eta] \propto K M^{\alpha}$, where the values of the parameters $K$ and $\alpha$ depend on the particular polymer solution system [95].

\subsubsection{Inhibition of Digestive Enzyme}

a-amylase and a-glucosidase are the two main enzymes necessary to hydrolyze carbohydrates in the digestive system. a-amylase can initiate carbohydrate hydrolysis by cleaving a-(1,4)-linked glycosidic bonds and yield smaller fractions, such as sucrose and maltose [96]. Then, a-glucosidase can hydrolyze these fractions into absorbable monosaccharides, such as glucose and fructose, during intestinal digestion [97]. Adequate free glucose can be generated after this digestive process, which may be excessively ingested into the bloodstream in T2D patients, leading to hyperglycemia. Therefore, inhibition of these enzymes to cause lower carbohydrate digestion can help control T2D. Ma et al. showed that a $\beta$-glucan adopting a triple helix conformation from Hericium erinaceus reduced wheat starch digestibility from $70 \%$ to less than $60 \%$ by inhibiting the digestive enzymes [98]. Qin et al. compared the glucose availability of the digestive system after adding different modified oat $\beta$-glucans, and all of these $\beta$-glucans decreased glucose availability, which indicated their potential hypoglycemic effect [17].

Lipases play an important role in hydrolyzing diet lipids; they convert lipids into cholesterol and fatty acids, which can be absorbed by enterocytes through lipid transporters [99]. Many studies have reported that $\beta$-glucans can inhibit lipase activity and therefore alleviate the hyperlipidemia seen in T2D. For example, barley $\beta$-glucans can slow lipolysis and reduce the release of free fatty acids; these inhibition effects were highly dependent on the molecular weights of the $\beta$-glucans [100].

There are some possible underlying mechanisms related to the enzyme inhibitor role of $\beta$-glucans, as shown in Figure 4 . For example, these $\beta$-glucans, which can only be fermented in the large intestine, play a physical barrier role in the digestive system to inhibit the activity of these digestive enzymes [101]. At the same time, $\beta$-glucans can inhibit these digestive enzymes by mixed competitive and uncompetitive inhibition to suppress enzyme-substrate interactions and therefore reduce the digestion of substrates [102]. Both of these proposed mechanisms rely on the physiological conformations of the $\beta$-glucans in vivo. For example, the binding between $\beta$-glucans and enzymes follows the lock-and-key principle; therefore, the shapes (confirmations) of $\beta$-glucans under physiological conditions are a decisive factor for binding efficiency, thereby controlling the inhibition effect of these $\beta$-glucans $[20,103]$.

It should be noted that other possible anti-diabetic mechanisms of $\beta$-glucans have been proposed. For example, the modulation effects of $\beta$-glucan on gut microbiota have been widely reported $[89,104]$. $\beta$-glucans can function as prebiotics, as they are mainly fermented in the large bowel and benefit the host-microbiota interactions in the whole gastrointestinal process. As a prebiotic, $\beta$-glucans alter the microbiota compositions by improving the number of beneficial bacteria, such as Lactobacillus, during large bowel fermentation $[105,106]$, leading to an increase in short-chain fatty acids (SCFA), which can improve the colonic defense barrier in T2D [107]. In addition, $\beta$-glucans can regulate the superoxide dismutase and malondialdehyde levels in the livers of diabetic mice [108]. However, these reported effects need to be further explored. For example some particular structural features of $\beta$-glucans may be preferred by these beneficial bacteria. Again a better understanding of the structure and function relationship of $\beta$-glucans may help yield more potent health benefits. 


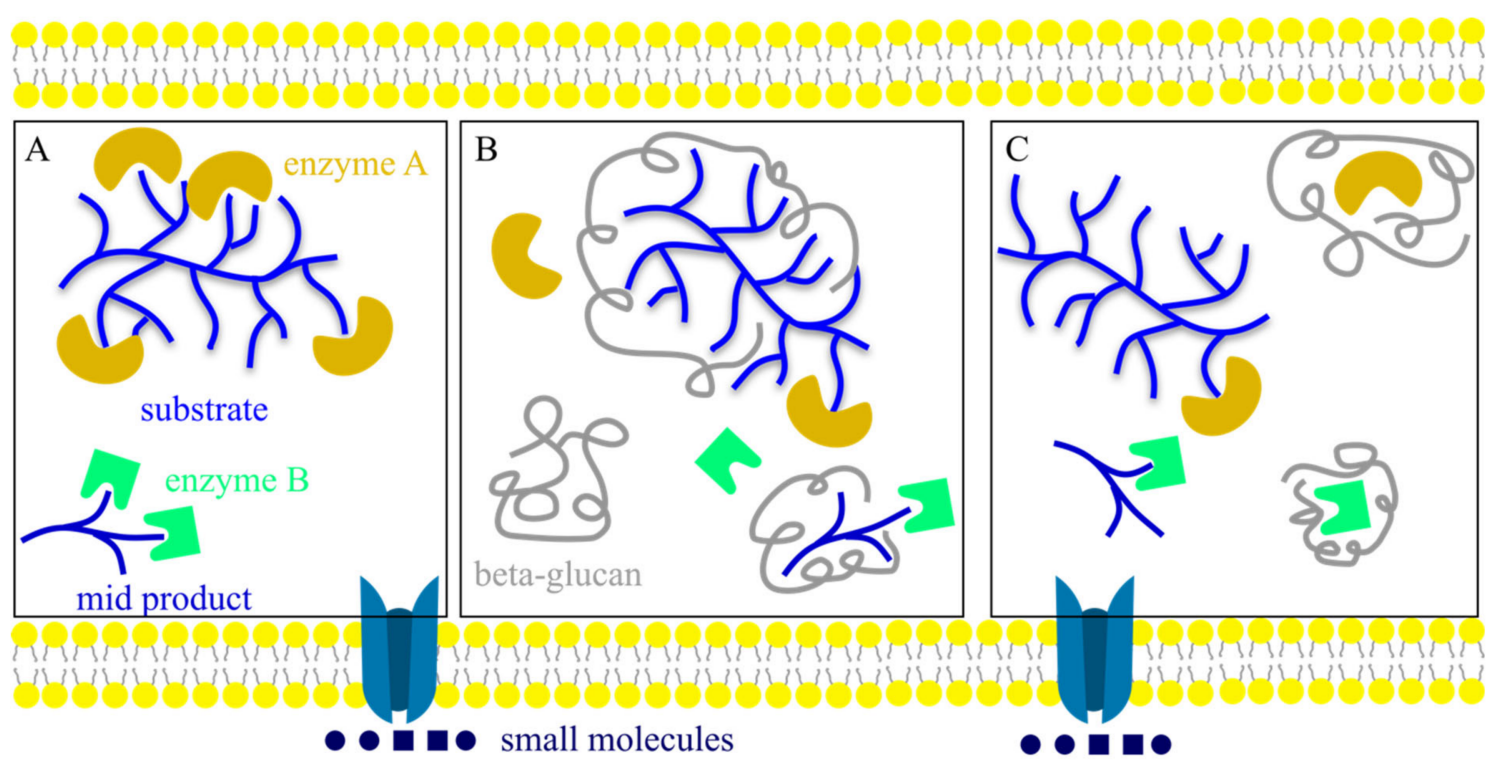

Figure 4. The proposed mechanism of enzyme inhibition. (A) The normal enzyme-substrate interactions during digestion. (B) $\beta$-glucans play as a physical barrier to inhibit enzyme-substrate interactions. (C) $\beta$-glucans bind to enzymes to inhibit enzyme-substrate interactions.

\section{Conclusions}

$\beta$-glucans are sustainable polymers that widely exist in natural resources. These biomacromolecules mainly contain $\beta$-(1,3)-linked, $\beta$-(1,4)-linked and $\beta$-(1,6)-linked glycosidic bonds, and adopt several different conformations in solutions, such as a helical conformation, which seems to be the origin of their versatile biofunctions and thus furnish a target for targeting efficacy. For a detailed characterization of $\beta$-glucans, both chemical and instrumental methods should be combined to give accurate structural and conformational features, which can then be linked to an understanding of their functionalities. Although there are many reported anti-diabetic mechanisms of $\beta$-glucans, only two mechanisms, retardation of macronutrient absorption and inhibition of digestive enzymes, can be well explained through their detailed structures and conformations. However, current research on the anti-diabetic functions of $\beta$-glucans is focused on naturally derived $\beta$-glucans. It would be worthwhile to explore the underlying anti-diabetic mechanisms using synthetic $\beta$-glucans with detailed structural information. With improved understanding of the structure/function relationship of these molecules, precision designs of $\beta$-glucans with particular structures and/or conformations could be produced to help control T2D.

Author Contributions: Y.W.: writing—original draft, writing—review \& editing. X.X.: writingreview \& editing, funding acquisition. M.A.S.: writing-review \& editing, supervision, funding acquisition. R.G.G.: writing - review \& editing, supervision, project administration, funding acquisition. All authors have read and agreed to the published version of the manuscript.

Funding: Y.W. gratefully acknowledges the support of a University of Queensland Research Training Scholarship. X.X. gratefully acknowledges financial support from National Natural Science Foundation of China (22075213, 21875167, and 21574102), National Key Research and Development Program of China (2016YFD0400202), and Key Research \& Development Program of Hubei province (2020BCA079). M.A.S. is supported by an Advance Queensland Industry Research Fellowship, Mater Foundation, Equity Trustees and the L G McCallam Est and George Weaber Trusts. For R.G.G., partial funding was from the National Natural Science Foundation of China, grant number C1304013151101138, and the Priority Academic Program of Jiangsu Higher Education Institutions.

Institutional Review Board Statement: Not applicable.

Informed Consent Statement: Not applicable.

Data Availability Statement: Not applicable. 
Conflicts of Interest: The authors declare no conflict of interest.

\section{References}

1. Association, A.D. Diagnosis and classification of diabetes mellitus. Diabetes Care 2014, 37, S81-S90. [CrossRef] [PubMed]

2. Cho, N.; Shaw, J.; Karuranga, S.; Huang, Y.; da Rocha Fernandes, J.; Ohlrogge, A.; Malanda, B. IDF Diabetes Atlas: Global estimates of diabetes prevalence for 2017 and projections for 2045. Diabetes Res. Clin. Pract. 2018, 138, 271-281. [CrossRef] [PubMed]

3. International Diabetes Federation. IDF Diabetes Atlas, 9th ed.; International Diabetes Federation: Brussels, Belgium, 2019.

4. Hu, Y.; Ding, B.; Shen, Y.; Yan, R.-N.; Li, F.-F.; Sun, R.; Jing, T.; Lee, K.-O.; Ma, J.-H. Rapid changes in serum testosterone in men with newly diagnosed type 2 diabetes with intensive insulin and metformin. Diabetes Care 2021, 44, 1059-1061. [CrossRef] [PubMed]

5. $\quad$ Ling, S.; Zaccardi, F.; Lawson, C.; Seidu, S.I.; Davies, M.J.; Khunti, K. Glucose control, sulfonylureas, and insulin treatment in elderly people with type 2 diabetes and risk of severe hypoglycemia and death: An observational study. Diabetes Care 2021, 44, 915-924. [CrossRef]

6. Han, S.; Hagan, D.L.; Taylor, J.R.; Xin, L.; Meng, W.; Biller, S.A.; Wetterau, J.R.; Washburn, W.N.; Whaley, J.M. Dapagliflozin, a selective SGLT2 inhibitor, improves glucose homeostasis in normal and diabetic rats. Diabetes 2008, 57, 1723-1729. [CrossRef] [PubMed]

7. Bae, J.; Huh, J.H.; Lee, M.; Lee, Y.H.; Lee, B.W. Glycaemic control with add-on thiazolidinedione or a sodium-glucose cotransporter-2 inhibitor in patients with type 2 diabetes after the failure of an oral triple antidiabetic regimen: A 24-week, randomized controlled trial. Diabetes Obes. Metab. 2021, 23, 609-618. [CrossRef]

8. Group, U.P.D.S. Effect of intensive blood-glucose control with metformin on complications in overweight patients with type 2 diabetes (UKPDS 34). Lancet 1998, 352, 854-865.

9. Bergenstal, R.; Lewin, A.; Bailey, T.; Chang, D.; Gylvin, T.; Roberts, V.; Group, N.M.-v.-E.S. Efficacy and safety of biphasic insulin aspart 70/30 versus exenatide in subjects with type 2 diabetes failing to achieve glycemic control with metformin and a sulfonylurea. Curr. Med. Res. Opin. 2009, 25, 65-75. [CrossRef]

10. Mafra, D.; Borges, N.A.; Lindholm, B.; Shiels, P.G.; Evenepoel, P.; Stenvinkel, P. Food as medicine: Targeting the uraemic phenotype in chronic kidney disease. Nat. Rev. Nephrol. 2020, 17, 153-171. [CrossRef]

11. Cui, L.; Chen, L.; Yang, G.; Li, Y.; Qiao, Z.; Liu, Y.; Meng, Y.; Zhou, Y.; Sun, L. Structural characterization and immunomodulatory activity of a heterogalactan from Panax ginseng flowers. Food Res. Int. 2021, 140, 109859. [CrossRef]

12. Wan, Y.; Shi, H.; Xu, R.; Yin, J.; Nie, S.; Xiong, T.; Xie, M. Origin of hypoglycemic benefits of probiotic-fermented carrot pulp. J. Agric. Food Chem. 2019, 67, 895-904. [CrossRef]

13. Song, Q.; Wang, Y.; Huang, L.; Shen, M.; Yu, Y.; Yu, Q.; Chen, Y.; Xie, J. Review of the relationships among polysaccharides, gut microbiota, and human health. Food Res. Int. 2020, 140, 109858. [CrossRef] [PubMed]

14. Chihara, G.; Hamuro, J.; Maeda, Y.Y.; Arai, Y.; Fukuoka, F. Fractionation and purification of the polysaccharides with marked antitumor activity, especially lentinan, from Lentinus edodes (Berk.) Sing.(an edible mushroom). Cancer Res. 1970, 30, $2776-2781$.

15. Chihara, G.; Maeda, Y.; Hamuro, J.; Sasaki, T.; Fukuoka, F. Inhibition of mouse sarcoma 180 by polysaccharides from Lentinus edodes (Berk.) sing. Nature 1969, 222, 687-688. [CrossRef]

16. El Enshasy, H.A.; Hatti-Kaul, R. Mushroom immunomodulators: Unique molecules with unlimited applications. Trends Biotechnol. 2013, 31, 668-677. [CrossRef] [PubMed]

17. Qin, Y.; Xie, J.; Xue, B.; Li, X.; Gan, J.; Zhu, T.; Sun, T. Effect of acid and oxidative degradation on the structural, rheological, and physiological properties of oat $\beta$-glucan. Food Hydrocoll. 2021, 112, 106284. [CrossRef]

18. Sun, T.; Li, J.; Qin, Y.; Xie, J.; Xue, B.; Li, X.; Gan, J.; Bian, X.; Shao, Z. Rheological and functional properties of oat $\beta$-glucan with different molecular weight. J. Mol. Struct. 2020, 1209, 127944. [CrossRef]

19. Xiao, J.B.; Jiang, H. A review on the structure-function relationship aspect of polysaccharides from tea materials. Crit. Rev. Food Sci. Nutr. 2015, 55, 930-938. [CrossRef]

20. Meng, Y.; Lyu, F.; Xu, X.; Zhang, L. Recent advances in chain conformation and bioactivities of triple-helix polysaccharides. Biomacromolecules 2020, 21, 1653-1677. [CrossRef]

21. Mejia, S.M.V.; de Francisco, A.; Bohrer, B.M. A comprehensive review on cereal beta-glucan: Extraction, characterization, causes of degradation, and food application. Crit. Rev. Food Sci. Nutr. 2020, 61, 3693-3704. [CrossRef]

22. Wang, J.T.; Xu, X.J.; Zheng, H.; Li, J.L.; Deng, C.; Xu, Z.H.; Chen, J.H. Structural characterization, chain conformation, and morphology of a beta-(1 - >3)-D-glucan isolated from the fruiting body of dictyophora indusiata. J. Agric. Food Chem. 2009, 57, 5918-5924. [CrossRef] [PubMed]

23. Deng, C.; Hu, Z.; Fu, H.; Hu, M.; Xu, X.; Chen, J. Chemical analysis and antioxidant activity in vitro of a beta-D-glucan isolated from Dictyophora indusiata. Int. J. Biol. Macromol. 2012, 51, 70-75. [CrossRef] [PubMed]

24. Hua, Y.; Yang, B.; Tang, J.; Ma, Z.; Gao, Q.; Zhao, M. Structural analysis of water-soluble polysaccharides in the fruiting body of Dictyophora indusiata and their in vivo antioxidant activities. Carbohydr. Polym. 2012, 87, 343-347. [CrossRef]

25. Zhang, R.; Edgar, K.J. Properties, chemistry, and applications of the bioactive polysaccharide curdlan. Biomacromolecules 2014, 15, 1079-1096. [CrossRef] 
26. Harada, T.; Misaki, A.; Saito, H. Curdlan-A Bacterial gel-forming beta-1 $\rightarrow 3$-glucan. Arch. Biochem. Biophys. 1968, 124, 292. [CrossRef]

27. Ahmad, A.; Anjum, F.M.; Zahoor, T.; Nawaz, H.; Ahmed, Z. Extraction and characterization of $\beta$-d-glucan from oat for industrial utilization. Int. J. Biol. Macromol. 2010, 46, 304-309. [CrossRef]

28. Gamel, T.H.; Abdel-Aal, E.-S.M.; Ames, N.P.; Duss, R.; Tosh, S.M. Enzymatic extraction of beta-glucan from oat bran cereals and oat crackers and optimization of viscosity measurement. J. Cereal Sci. 2014, 59, 33-40. [CrossRef]

29. Okobira, T.; Miyoshi, K.; Uezu, K.; Sakurai, K.; Shinkai, S. Molecular dynamics studies of side chain effect on the $\beta$-1, 3-D-glucan triple helix in aqueous solution. Biomacromolecules 2008, 9, 783-788. [CrossRef]

30. Zhong, K.; Tong, L.; Liu, L.; Zhou, X.; Liu, X.; Zhang, Q.; Zhou, S. Immunoregulatory and antitumor activity of schizophyllan under ultrasonic treatment. Int. J. Biol. Macromol. 2015, 80, 302-308. [CrossRef] [PubMed]

31. Zhang, Y.; Li, S.; Wang, X.; Zhang, L.; Cheung, P.C.K. Advances in lentinan: Isolation, structure, chain conformation and bioactivities. Food Hydrocoll. 2011, 25, 196-206. [CrossRef]

32. Meng, Y.; Shi, X.; Cai, L.; Zhang, S.; Ding, K.; Nie, S.; Luo, C.; Xu, X.; Zhang, L. Triple-helix conformation of a polysaccharide determined with light scattering, afm, and molecular dynamics simulation. Macromolecules 2018, 51, 10150-10159. [CrossRef]

33. Xu, S.; Lin, Y.; Huang, J.; Li, Z.; Xu, X.; Zhang, L. Construction of high strength hollow fibers by self-assembly of a stiff polysaccharide with short branches in water. J. Mater. Chem. A 2013, 1, 4198-4206. [CrossRef]

34. Ping, Z.H.; Xu, H.; Liu, T.; Huang, J.C.; Meng, Y.; Xu, X.J.; Li, W.H.; Zhang, L.N. Anti-hepatoma activity of the stiff branched beta-D-glucan and effects of molecular weight. J. Mat. Chem. B 2016, 4, 4565-4573. [CrossRef] [PubMed]

35. Dong, Q.; Jia, L.M.; Fang, J.N. A beta-D-glucan isolated from the fruiting bodies of Hericium erinaceus and its aqueous conformation Carbohydr. Res. 2006, 341, 791-795. [CrossRef]

36. Wu, D.; Tang, C.; Liu, Y.; Li, Q.; Wang, W.; Zhou, S.; Zhang, Z.; Cui, F.; Yang, Y. Structural elucidation and immunomodulatory activity of a beta-D-glucan prepared by freeze-thawing from Hericium erinaceus. Carbohydr. Polym. 2019, 222, 114996. [CrossRef]

37. Cui, H.; Zhu, X.; Huo, Z.; Liao, B.; Huang, J.; Wang, Z.; Song, C.; Hu, X.; Fang, J. A beta-glucan from Grifola frondosa effectively delivers therapeutic oligonucleotide into cells via dectin-1 receptor and attenuates TNFalpha gene expression. Int. J. Biol. Macromol. 2020, 149, 801-808. [CrossRef] [PubMed]

38. Iino, K.; Ohno, N.; Suzuki, I.; Miyazaki, T.; Yadomae, T.; Oikawa, S.; Sato, K. Structural characterisation of a neutral antitumour $\beta$-d-glucan extracted with hot sodium hydroxide from cultured fruit bodies of Grifola frondosa. Carbohydr. Res. 1985, 141, 111-119. [CrossRef]

39. Fang, J.; Wang, Y.; Lv, X.; Shen, X.; Ni, X.; Ding, K. Structure of a $\beta$-glucan from Grifola frondosa and its antitumor effect by activating Dectin-1/Syk/NF-kB signaling. Glycoconj. J. 2012, 29, 365-377. [CrossRef] [PubMed]

40. Kim, Y.-R.; Hwang, J.; Koh, H.-J.; Jang, K.; Lee, J.-D.; Choi, J.; Yang, C.-S. The targeted delivery of the c-Src peptide complexed with schizophyllan to macrophages inhibits polymicrobial sepsis and ulcerative colitis in mice. Biomaterials 2016, 89, 1-13. [CrossRef]

41. Kadam, S.U.; Tiwari, B.K.; O'Donnell, C.P. Extraction, structure and biofunctional activities of laminarin from brown algae. Int. J. Food Sci. Technol. 2015, 50, 24-31. [CrossRef]

42. Shin, H.J.; Oh, S.J.; Kim, S.I.; Won Kim, H.; Son, J.-H. Conformational characteristics of $\beta$-glucan in laminarin probed by terahertz spectroscopy. Appl. Phys. Lett. 2009, 94, 111911. [CrossRef]

43. Zhang, Y.; Xu, X.; Zhang, L. Gel formation and low-temperature intramolecular conformation transition of a triple-helical polysaccharide lentinan in water. Biopolymers 2008, 89, 852-861. [CrossRef]

44. Kao, P.F.; Wang, S.H.; Hung, W.T.; Liao, Y.H.; Lin, C.M.; Yang, W.B. Structural characterization and antioxidative activity of low-molecular-weights beta-1,3-glucan from the residue of extracted ganoderma lucidum fruiting bodies. J. Biomed. Biotechnol. 2012, 2012, 673764. [CrossRef] [PubMed]

45. Liu, Y.; Zhang, J.; Tang, Q.; Yang, Y.; Guo, Q.; Wang, Q.; Wu, D.; Cui, S.W. Physicochemical characterization of a high molecular weight bioactive beta-D-glucan from the fruiting bodies of Ganoderma lucidum. Carbohydr. Polym. 2014, 101, 968-974. [CrossRef]

46. Aimanianda, V.; Clavaud, C.; Simenel, C.; Fontaine, T.; Delepierre, M.; Latgé, J.-P. Cell wall $\beta$ - $(1,6)$-glucan of Saccharomyces cerevisiae: Structural characterization and in situ synthesis. J. Biol. Chem. 2009, 284, 13401-13412. [CrossRef] [PubMed]

47. Wang, J.; Chen, S.; Nie, S.; Cui, S.W.; Wang, Q.; Phillips, A.O.; Phillips, G.O.; Xie, M. Structural characterization and chain conformation of water-soluble $\beta$-glucan from wild cordyceps sinensis. J. Agric. Food Chem. 2019, 67, 12520-12527. [CrossRef] [PubMed]

48. Cui, W.; Wood, P. Relationships Between Structural Features, Molecular Weight and Rheological Properties of Cereal $\beta$-D-Glucans. In Hydrocolloids; Elsevier: Amstardam, The Netherlands, 2000; pp. 159-168.

49. De Arcangelis, E.; Djurle, S.; Andersson, A.A.M.; Marconi, E.; Messia, M.C.; Andersson, R. Structure analysis of $\beta$-glucan in barley and effects of wheat $\beta$-glucanase. J. Cereal Sci. 2019, 85, 175-181. [CrossRef]

50. Roubroeks, J.; Andersson, R.; Åman, P. Structural features of $(1 \rightarrow 3),(1 \rightarrow 4)-\beta$-D-glucan and arabinoxylan fractions isolated from rye bran. Carbohydr. Polym. 2000, 42, 3-11. [CrossRef]

51. Wood, P.; Weisz, J.; Blackwell, B. Molecular characterization of cereal $\beta$-D-glucans. Structural analysis of oat $\beta$-D-glucan and rapid structural evaluation of $\beta$-D-glucans from different sources by high-performance liquid chromatography of oligosaccharides released by lichenase. Cereal Chem. 1991, 68, 31-39. 
52. Wood, P.; Weisz, J.; Blackwell, B. Structural studies of $(1 \rightarrow 3),(1 \rightarrow 4)-\beta$-D-glucans by 13 C-nuclear magnetic resonance spectroscopy and by rapid analysis of cellulose-like regions using high-performance anion-exchange chromatography of oligosaccharides released by lichenase. Cereal Chem. 1994, 71, 301-307.

53. Beer, M.U.; Wood, P.J.; Weisz, J.; Fillion, N. Effect of cooking and storage on the amount and molecular weight of $(1 \rightarrow 3)(1 \rightarrow 4)-\beta-$ D-glucan extracted from oat products by an in vitro digestion system. Cereal Chem. 1997, 74, 705-709. [CrossRef]

54. Yuan, H.J.; Lan, P.; He, Y.; Li, C.L.; Ma, X. Effect of the modifications on the physicochemical and biological properties of beta-glucan-A critical review. Molecules 2020, 25, 57. [CrossRef]

55. Zheng, X.; Zhou, F.; Xu, X.; Zhang, L. Uptake of intraperitoneally administrated triple helical $\beta$-glucan for antitumor activity in murine tumor models. J. Mat. Chem. B 2017, 5, 9337-9345. [CrossRef] [PubMed]

56. Cai, Z.; Zhang, H. Recent progress on curdlan provided by functionalization strategies. Food Hydrocoll. 2017, 68, 128-135. [CrossRef]

57. Geller, A.; Shrestha, R.; Yan, J. Yeast-derived beta-glucan in cancer: Novel uses of a traditional therapeutic. Int. J. Mol. Sci. 2019, 20, 618. [CrossRef] [PubMed]

58. Zheng, X.; Lu, F.Z.; Xu, X.J.; Zhang, L.N. Extended chain conformation of beta-glucan and its effect on antitumor activity. J. Mat. Chem. B 2017, 5, 5623-5631. [CrossRef]

59. Yanaki, T.; Norisuye, T.; Fujita, H. Triple helix of Schizophyllum commune polysaccharide in dilute solution. 3. Hydrodynamic properties in water. Macromolecules 1980, 13, 1462-1466. [CrossRef]

60. Xu, S.; Xu, X.; Zhang, L. Effect of heating on chain conformation of branched $\beta$-glucan in water. J. Phys. Chem. B 2013, 117, 8370-8377. [CrossRef]

61. Zhang, X.; Zhang, L.; Xu, X. Morphologies and conformation transition of lentinan in aqueous NaOH solution. Biopolym. Orig. Res. Biomol. 2004, 75, 187-195.

62. Xu, X.; Zhang, X.; Zhang, L.; Wu, C. Collapse and association of denatured lentinan in water/dimethlysulfoxide solutions. Biomacromolecules 2004, 5, 1893-1898. [CrossRef]

63. Edge, C.; Parekh, R.; Rademacher, T.; Wormald, M.; Dwek, R. Fast sequencing of oligosaccharides using arrays of enzymes. Nature 1992, 358, 693-694. [CrossRef]

64. Venkataraman, G.; Shriver, Z.; Raman, R.; Sasisekharan, R. Sequencing complex polysaccharides. Science 1999, $286,537-542$. [CrossRef] [PubMed]

65. Hofmann, J.; Hahm, H.; Seeberger, P.H.; Pagel, K. Identification of carbohydrate anomers using ion mobility-mass spectrometry Nature 2015, 526, 241-244. [CrossRef] [PubMed]

66. Rief, M.; Oesterhelt, F.; Heymann, B.; Gaub, H.E. Single molecule force spectroscopy on polysaccharides by atomic force microscopy. Science 1997, 275, 1295-1297. [CrossRef] [PubMed]

67. Li, Y.-Q.; Bruun, L.; Pierson, E.S.; Cresti, M. Periodic deposition of arabinogalactan epitopes in the cell wall of pollen tubes of Nicotiana tabacum L. Planta 1992, 188, 532-538. [CrossRef]

68. Wu, X.; Delbianco, M.; Anggara, K.; Michnowicz, T.; Pardo-Vargas, A.; Bharate, P.; Sen, S.; Pristl, M.; Rauschenbach, S.; Schlickum, U.; et al. Imaging single glycans. Nature 2020, 582, 375-378. [CrossRef]

69. Li, B.; Zhang, N.; Feng, Q.; Li, H.; Wang, D.; Ma, L.; Liu, S.; Chen, C.; Wu, W.; Jiao, L. The core structure characterization and of ginseng neutral polysaccharide with the immune-enhancing activity. Int. J. Biol. Macromol. 2019, 123, 713-722. [CrossRef]

70. Lee, Y.C. Carbohydrate analyses with high-performance anion-exchange chromatography. J. Chromatogr. A 1996, 720, 137-149. [CrossRef]

71. Kono, H.; Kondo, N.; Isono, T.; Ogata, M.; Hirabayashi, K. Characterization of the secondary structure and order-disorder transition of a $\beta-(1 \rightarrow 3,1 \rightarrow 6)$-glucan from Aureobasidium pullulans. Int. J. Biol. Macromol. 2020, 154, 1382-1391. [CrossRef]

72. Roden, M.; Shulman, G.I. The integrative biology of type 2 diabetes. Nature 2019, 576, 51-60. [CrossRef]

73. Mahajan, A.; Wessel, J.; Willems, S.M.; Zhao, W.; Robertson, N.R.; Chu, A.Y.; Gan, W.; Kitajima, H.; Taliun, D.; Rayner, N.W. Refining the accuracy of validated target identification through coding variant fine-mapping in type 2 diabetes. Nat. Genet. 2018, 50, 559-571. [CrossRef] [PubMed]

74. Varanko, A.K.; Chilkoti, A. Molecular and materials engineering for delivery of peptide drugs to treat type 2 diabetes. Adv. Healthc. Mater. 2019, 8, 1801509. [CrossRef] [PubMed]

75. Cabré, C.; Colungo, C.; Vinagre, I.; Jansà, M.; Conget, I. Frequency and awareness of hypoglycemia in patients with Type 2 Diabetes treated with two or more insulin injections in primary care outpatient clinics. Prim. Care Diabetes 2020, 14, 168-172. [CrossRef] [PubMed]

76. Wu, H.; Esteve, E.; Tremaroli, V.; Khan, M.T.; Caesar, R.; Mannerås-Holm, L.; Ståhlman, M.; Olsson, L.M.; Serino, M.; PlanasFèlix, M. Metformin alters the gut microbiome of individuals with treatment-naive type 2 diabetes, contributing to the therapeutic effects of the drug. Nat. Med. 2017, 23, 850. [CrossRef]

77. Cabreiro, F.; Au, C.; Leung, K.-Y.; Vergara-Irigaray, N.; Cochemé, H.M.; Noori, T.; Weinkove, D.; Schuster, E.; Greene, N.D.; Gems, D. Metformin retards aging in C. elegans by altering microbial folate and methionine metabolism. Cell 2013, 153, 228-239. [CrossRef] 
78. Nauck, M.A.; Meininger, G.; Sheng, D.; Terranella, L.; Stein, P.P.; Sitagliptin Study Group. Efficacy and safety of the dipeptidyl peptidase-4 inhibitor, sitagliptin, compared with the sulfonylurea, glipizide, in patients with type 2 diabetes inadequately controlled on metformin alone: A randomized, double-blind, non-inferiority trial. Diabetes Obes. Metab. 2007, 9, 194-205. [CrossRef]

79. Proks, P.; Reimann, F.; Green, N.; Gribble, F.; Ashcroft, F. Sulfonylurea stimulation of insulin secretion. Diabetes 2002, 51, S368-S376. [CrossRef]

80. Pajvani, U.B.; Hawkins, M.; Combs, T.P.; Rajala, M.W.; Doebber, T.; Berger, J.P.; Wagner, J.A.; Wu, M.; Knopps, A.; Xiang, A.H Complex distribution, not absolute amount of adiponectin, correlates with thiazolidinedione-mediated improvement in insulin sensitivity. J. Biol. Chem. 2004, 279, 12152-12162. [CrossRef]

81. Zhang, H.; Zhang, A.; Kohan, D.E.; Nelson, R.D.; Gonzalez, F.J.; Yang, T. Collecting duct-specific deletion of peroxisome proliferator-activated receptor $\gamma$ blocks thiazolidinedione-induced fluid retention. Proc. Natl. Acad. Sci. USA 2005, 102, 9406-9411. [CrossRef]

82. Drucker, D.J. Biological actions and therapeutic potential of the glucagon-like peptides. Gastroenterology 2002, 122, 531-544. [CrossRef]

83. Bettge, K.; Kahle, M.; Abd El Aziz, M.S.; Meier, J.J.; Nauck, M.A. Occurrence of nausea, vomiting and diarrhoea reported as adverse events in clinical trials studying glucagon-like peptide-1 receptor agonists: A systematic analysis of published clinical trials. Diabetes Obes. Metab. 2017, 19, 336-347. [CrossRef] [PubMed]

84. Herman, G.A.; Stevens, C.; van Dyck, K.; Bergman, A.; Yi, B.; de Smet, M.; Snyder, K.; Hilliard, D.; Tanen, M.; Tanaka, W. Pharmacokinetics and pharmacodynamics of sitagliptin, an inhibitor of dipeptidyl peptidase IV, in healthy subjects: Results from two randomized, double-blind, placebo-controlled studies with single oral doses. Clin. Pharmacol. Ther. 2005, 78, 675-688. [CrossRef] [PubMed]

85. Fadini, G.P.; Avogaro, A. Cardiovascular effects of DPP-4 inhibition: Beyond GLP-1. Vasc. Pharmacol. 2011, 55, 10-16. [CrossRef] [PubMed]

86. Lambeir, A.-M.; Scharpé, S.; de Meester, I. DPP4 inhibitors for diabetes-What next? Biochem. Pharmacol. 2008, 76, 1637-1643. [CrossRef]

87. Taylor, S.I.; Blau, J.E.; Rother, K.I. SGLT2 inhibitors may predispose to ketoacidosis. J. Clin. Endocrinol. Metab. 2015, 100, $2849-2852$. [CrossRef]

88. Tundis, R.; Loizzo, M.; Menichini, F. Natural products as $\alpha$-amylase and $\alpha$-glucosidase inhibitors and their hypoglycaemic potential in the treatment of diabetes: An update. Mini Rev. Med. Chem. 2010, 10, 315-331. [CrossRef] [PubMed]

89. Pino, J.L.; Mujica, V.; Arredondo, M. Effect of dietary supplementation with oat $\beta$-glucan for 3 months in subjects with type 2 diabetes: A randomized, double-blind, controlled clinical trial. J. Funct. Foods 2021, 77, 104311. [CrossRef]

90. Maki, K.; Galant, R.; Samuel, P.; Tesser, J.; Witchger, M.; Ribaya-Mercado, J.; Blumberg, J.; Geohas, J. Effects of consuming foods containing oat $\beta$-glucan on blood pressure, carbohydrate metabolism and biomarkers of oxidative stress in men and women with elevated blood pressure. Eur. J. Clin. Nutr. 2007, 61, 786-795. [CrossRef]

91. Zhao, C.; Yang, C.; Liu, B.; Lin, L.; Sarker, S.D.; Nahar, L.; Yu, H.; Cao, H.; Xiao, J. Bioactive compounds from marine macroalgae and their hypoglycemic benefits. Trends Food Sci. Technol. 2018, 72, 1-12. [CrossRef]

92. Nishinari, K.; Takemasa, M.; Fang, Y.; Hossain, K.S.; Tsumura, Y.; Sone, Y.; Fujiwara, M.; Habu, D.; Emoto, M. Effects of xyloglucan with different molar masses on glucose in blood. Food Hydrocoll. 2020, 108, 105727. [CrossRef]

93. Wood, P.; Beer, M.; Butler, G. Evaluation of role of concentration and molecular weight of oat $\beta$-glucan in determining effect of viscosity on plasma glucose and insulin following an oral glucose load. Br. J. Nutr. 2000, 84, 19-23. [CrossRef]

94. Tosh, S.M.; Bordenave, N. Emerging science on benefits of whole grain oat and barley and their soluble dietary fibers for heart health, glycemic response, and gut microbiota. Nutr. Rev. 2020, 78, 13-20. [CrossRef]

95. Liu, Y.; Wang, Y.; Zhou, S.; Yan, M.; Tang, Q.; Zhang, J. Structure and chain conformation of bioactive $\beta$-D-glucan purified from water extracts of Ganoderma lucidum unbroken spores. Int. J. Biol. Macromol. 2021, 180, 484-493. [CrossRef] [PubMed]

96. Bai, Y.; Atluri, S.; Zhang, Z.; Gidley, M.J.; Li, E.; Gilbert, R.G. Structural reasons for inhibitory effects of pectin on $\alpha$-amylase enzyme activity and in-vitro digestibility of starch. Food Hydrocoll. 2021, 114, 106581. [CrossRef]

97. Gong, X.; Sui, L.; Morton, J.; Brennan, M.A.; Brennan, C.S. Investigation of nutritional and functional effects of rice bran protein hydrolysates by using Preferred Reporting Items for Systematic Reviews and Meta-Analysis (PRISMA) guidelines: A review. Trends Food Sci. Technol. 2021, 110, 798-811. [CrossRef]

98. Ma, B.; Feng, T.; Zhang, S.; Zhuang, H.; Chen, D.; Yao, L. The inhibitory effects of Hericium erinaceus $\beta$-glucan on in vitro starch digestion. Front. Nutr. 2020, 7, 348. [CrossRef] [PubMed]

99. Singh, B.P.; Aluko, R.E.; Hati, S.; Solanki, D. Bioactive peptides in the management of lifestyle-related diseases: Current trends and future perspectives. Crit. Rev. Food Sci. Nutr. 2021, 1-14. [CrossRef] [PubMed]

100. Zhai, H.; Gunness, P.; Gidley, M.J. Barley $\beta$-glucan effects on emulsification and in vitro lipolysis of canola oil are modulated by molecular size, mixing method, and emulsifier type. Food Hydrocoll. 2020, 103, 105643. [CrossRef]

101. Zhang, H.; Li, Z.; Tian, Y.; Song, Z.; Ai, L. Interaction between barley $\beta$-glucan and corn starch and its effects on the in vitro digestion of starch. Int. J. Biol. Macromol. 2019, 141, 240-246. [CrossRef]

102. Gong, L.; Feng, D.; Wang, T.; Ren, Y.; Liu, Y.; Wang, J. Inhibitors of $\alpha$-amylase and $\alpha$-glucosidase: Potential linkage for whole cereal foods on prevention of hyperglycemia. Food Sci. Nutr. 2020, 8, 6320-6337. [CrossRef] 
103. Fukuhara, G. Analytical supramolecular chemistry: Colorimetric and fluorimetric chemosensors. J. Photochem. Photobiol. C Photochem. Rev. 2020, 42, 100340. [CrossRef]

104. Tan, H.; Nie, S. Functional hydrocolloids, gut microbiota and health: Picking food additives for personalized nutrition. FEMS Microbiol. Rev. 2021, 45, fuaa065. [CrossRef]

105. Velikonja, A.; Lipoglavšek, L.; Zorec, M.; Avguštin, G. Alterations in gut microbiota composition and metabolic parameters after dietary intervention with barley beta glucans in patients with high risk for metabolic syndrome development. Anaerobe 2019, 55, 67-77. [CrossRef] [PubMed]

106. Wang, Y.; Ames, N.P.; Tun, H.M.; Tosh, S.M.; Jones, P.J.; Khafipour, E. High molecular weight barley $\beta$-glucan alters gut microbiota toward reduced cardiovascular disease risk. Front. Microbiol. 2016, 7, 129. [CrossRef] [PubMed]

107. Liu, P.; Wang, Y.; Yang, G.; Zhang, Q.; Meng, L.; Xin, Y.; Jiang, X. The role of short-chain fatty acids in intestinal barrier function, inflammation, oxidative stress, and colonic carcinogenesis. Pharmacol. Res. 2021, 165, 105420. [CrossRef] [PubMed]

108. Zhao, Q.; Hu, X.; Guo, Q.; Cui, S.W.; Xian, Y.; You, S.; Chen, X.; Xu, C.; Gao, X. Physicochemical properties and regulatory effects on $\mathrm{db} / \mathrm{db}$ diabetic mice of $\beta$-glucans extracted from oat, wheat and barley. Food Hydrocoll. 2014, 37, 60-68. [CrossRef] 